\title{
T cell cytotoxicity to Epstein-Barr virus infected B cells: comparison of patients with rheumatoid arthritis and their HLA identical siblings
}

\author{
VIVIENNE R WINROW,' JANICE NORTON,' E JOHN HOLBOROW, \\ HELMUT E STIERLE, ${ }^{1 *}$ ADAM YOUNG, ${ }^{2}$ AND JOHN A SACHS \\ From the 'ARC Bone and Joint Research Unit, The London Hospital Medical College, London; and \\ ${ }^{2}$ St Alban's City Hospital, Herts, England
}

SUMmary Specific T cell cytotoxicity to Epstein-Barr virus (EBV) infected B cells is reported to $\stackrel{\infty}{O}^{\infty}$ be abnormal in rheumatoid arthritis (RA). The regression phenomenon was used to determine 은 whether the immunoregulatory defect in RA is restricted to T cells, B cells, or HLA type. Peripheral blood T and B cells from patients with RA and their HLA identical healthy siblings $\frac{D}{0}$ were mixed in varying ratios with and without EBV, and thymidine incorporation was measured on days 7,14 , and 21 . The results suggest that the $T$ cell abnormality is related to disease activity and that an inherent defect exists in the rheumatoid B cell which is independent of disease activity.

Key words: T lymphocyte, immune regulation.

The underlying deficiency of immunoregulation in rheumatoid arthritis (RA) is unknown, though disturbances in humoral and cellular immunity are well documented. The Epstein-Barr virus (EBV), originally implicated in the pathogenesis of RA, ${ }^{12}$ has since been used to study the cellular immunity defect in RA through its ability to transform B lymphocytes into lymphoblastoid cell lines in vitro. Healthy individuals previously infected with EBV possess specific memory $T$ cells which can abrogate $B$ cell outgrowth in mononuclear cell cultures after superinfection with the virus ('regression'3), whereas rheumatoid $\mathrm{T}$ cells appear to show impairment of this ability. ${ }^{4-7}$ An alternative explanation is that it is not poor $T$ cell regulation but an inherent defect in rheumatoid $B$ cells which renders them unresponsive to regulation. ${ }^{8-10}$ In this study specific $\mathrm{T}$ cell cytotoxicity to EBV infected B cells was measured using blood lymphocytes from patients and their HLA identical siblings to ascertain whether the immunoregulatory defect in RA is governed by $\mathrm{B}$ cell or $\mathrm{T}$ cell behaviour.

Accepted for publication 1 October 1987.

Correspondence to Dr Vivienne R Winrow, ARC Bone and Joint Research Unit, The London Hospital Medical College, 25-29 Ashfield Street, London E1 2AD.

*Present address: II Med Abtl, Krankenhaus der Barmherzigen, Brüder, D5500 Trier, FRG.

\section{Patients and methods}

PATIENTS

Families of patients at St Alban's Hospital were recruited and disease activity assessed clinically (AY). Each family consisted of a patient with classical RA and at least two apparently healthy siblings. Tissue typing was performed in the immunology department of the London Hospital Medical College by standard procedures.

\section{CELL SEPARATION}

On the day of collection venous peripheral blood mononuclear cells were isolated by flotation ${ }^{11}$ on Lymphoprep (Nyegaard), washed in serum free medium, and resuspended in RPMI 1640 with L-glutamine to which had been added $10 \%$ fetal calf serum and 100 units $/ \mathrm{ml}$ of penicillin/streptomycin (culture medium; Gibco Biocult). The cells were mixed with 2-aminoethylisothiouronium bromide hydrobromide treated sheep erythrocytes, ${ }^{12}$ pelleted, maintained at $4^{\circ} \mathrm{C}$ for 60 minutes, and gently resuspended. The suspension was layered on Lymphoprep and the rosetted $T$ cells separated from the non-T cells. Erythrocytes were removed from the enriched $\mathrm{T}$ cell population in the pellet by lysis with $0.83 \%$ ammonium chloride, and the cells were washed in serum free medium and resuspended to a 
final concentration of $5 \times 10 \% / \mathrm{ml}$ in culture medium. Non-T cells recovered from the interface were washed and resuspended at a concentration of $5 \times 10^{5} / \mathrm{ml}$ in culture medium or were incubated with $\mathrm{EBV}$ in culture medium for one hour at $37^{\circ} \mathrm{C}$ before washing and resuspending at $5 \times 10^{5} / \mathrm{ml}$ in culture medium.

\section{EBV PREPARATION}

Epstein-Barr virus, used for B cell transformation, was obtained from 10 day culture supernatants of the marmoset cell line B95-8 and titrated against fetal cord blood cells. The virus preparation used for all experiments was stored in aliquots in liquid nitrogen, each aliquot being thawed once immediately before use and used at a final dilution of 1 in 10 .

\section{OUTGROWTH ASSAY}

Unfractionated mononuclear cells and $\mathrm{T}$ and non- $\mathrm{T}$ cells $\left(5 \times 10^{5} / \mathrm{ml}\right)$ were incubated separately in 24 well, flat bottomed plates (Nunc) with and without EBV for six weeks. Duplicate or triplicate cultures $(1 \mathrm{ml})$ were set up, depending on cell numbers, and the medium was replaced weekly. B cell outgrowth was scored visually every two or three days using the method of Thorley-Lawson, Chess, and Strominger ${ }^{1.3}$ to check for induced or spontaneous outgrowth of cell lines and bacterial contamination.

REGRESSION ASSAY

$T$ and non- $T$ cells were added to 96-well, flat bottomed microtitre plates (Nunc) to give a final cell number of $1 \times 10^{5}$ in $200 \mu \mathrm{l}$ culture medium. T/non-T cell ratios of $100 /(0,90 / 10,75 / 25,50 / 50,25 / 75,10 / 90$, and $0 / 100$ were used. EBV infected non-T cells from each sibling were mixed with either autologous $T$ cells or allogeneic $T$ cells from an HLA identical sibling. The cultures were set up in triplicate on each of three plates and a fourth control well contained cell mixtures without EBV to check for mixed lymphocyte reactions; non-T cell numbers were too small to set up triplicate samples of control wells. The plates were incubated at $37^{\circ} \mathrm{C}$ in a humidified atmosphere of $5 \% \mathrm{CO}_{2}$ for up to three weeks and the culture medium replaced on days 6,13 , and 20 . Each week, immediately after feeding, $37 \mathrm{kBq}$ of $\left[{ }^{3} \mathrm{H}\right]$ thymidine was added to each well of one plate, and 18 hours later the cells were harvested on glass microfibre discs (Whatman GF/A), dried, and counted (Kontron MR300) using a toluene based scintillant. Before harvesting, cell cultures were scored for B cell outgrowth as above.

\section{Results}

In only three of eight families tissue typed were siblings found of the same HLA identity as the patient (Table 1). The results for families 1 and 2 will be discussed in detail here. In both families the patients were DR4 positive and had longstanding seropositive RA. The patient in family 1 had clinically active disease according to American Rheumatism Association criteria ${ }^{1+}$ at the time of

Table 2 Correlation of outgrowth with proliferation of $E B V$ infected rheumatoid $B$ cells cultured with autologous and homologous $T$ cells (family 1, day 14)

\begin{tabular}{|c|c|c|c|c|c|}
\hline \multirow{2}{*}{$\begin{array}{l}\text { Patient } \\
B \text { cells } \\
(\%)\end{array}$} & \multirow[t]{2}{*}{$\begin{array}{l}T \text { cells } \\
(\%)\end{array}$} & \multicolumn{2}{|c|}{ Patient $T$ cells } & \multicolumn{2}{|c|}{$\begin{array}{l}\text { Healthy } T \text { cells } \\
\text { (sibling } A \text { ) }\end{array}$} \\
\hline & & $\begin{array}{l}+E B V \\
(c p m)^{*}\end{array}$ & $\begin{array}{l}T-L^{+} \\
\text {score }\end{array}$ & $\begin{array}{l}+E B V \\
(c p m)^{*}\end{array}$ & $\begin{array}{l}T-L \\
\text { score }\end{array}$ \\
\hline 100 & () & 11105 & 4 & & \\
\hline 90 & 10 & 16824 & 4 & 16821 & 3 \\
\hline 75 & 25 & 16026 & 4 & 18199 & 4 \\
\hline 50 & 50 & 18196 & 4 & 6479 & $3 / 1$ \\
\hline 25 & 75 & 19946 & 4 & 3729 & $3 / 1$ \\
\hline 10 & 90 & 8948 & $4 / 1$ & 575 & $2 / 1$ \\
\hline () & $10(0)$ & 1113 & $2 / 1$ & 484 & $2 / 1$ \\
\hline
\end{tabular}

* The mean $\mathrm{cpm}$ of triplicate samples is shown.

†Thorley-Lawson score ( $\geqslant$ two wells).

Table 1 Tissue types of disease discordant siblings and clinical details and treatment of rheumatoid patients

\begin{tabular}{|c|c|c|c|c|}
\hline $\begin{array}{l}\text { Family } \\
\text { (total number } \\
\text { of siblings) }\end{array}$ & $\begin{array}{l}\text { Disease } \\
\text { discordant } \\
\text { siblings }\end{array}$ & HLA type & Age/sex & Clinical notes and treatment \\
\hline $1(6)$ & $\begin{array}{l}\text { RA patient } \\
\text { Sibling A } \\
\text { Sibling B }\end{array}$ & A2.3: B7.w62: DR2.4 & $\begin{array}{l}46 / \mathrm{M} \\
52 / \mathrm{M} \\
40 / \mathrm{F}\end{array}$ & $\begin{array}{l}\text { Seropositive: } 11 \text { years RA with intermittent active } \\
\text { disease. Indomethacin/D-penicillamine/low dose } \\
\text { steroid }\end{array}$ \\
\hline $2(3)$ & $\begin{array}{l}\text { RA patient } \\
\text { Sibling A } \\
\text { Sibling B }\end{array}$ & A $31.32: B 44.51:$ DR4.7 & $\begin{array}{l}72 / \mathrm{F} \\
68 / \mathrm{F} \\
75 / \mathrm{F}\end{array}$ & $\begin{array}{l}\text { Seropositive. 'burnt out: } 15 \text { years RA with } \\
\text { inactive disease for four years. Paracetamol }\end{array}$ \\
\hline $3(4)$ & $\begin{array}{l}\text { RA patient } \\
\text { Sibling A }\end{array}$ & A2,11: B44.49; Cw5.w7 & $\begin{array}{l}/ \mathrm{F} \\
/ \mathrm{F}\end{array}$ & Seropositive with active disease \\
\hline
\end{tabular}


assay, whereas in the patient in family 2 disease had been inactive for the last four years before testing. Inactive disease was defined as early morning stiffness of less than 30 minutes, joint symptoms ascribed to mechanical damage or primary or secondary osteoarthritis, and an erythrocyte sedimentation rate of less than $25 \mathrm{~mm} / \mathrm{h}$. ${ }^{15}$ Table 1 also shows the treatments for these two patients.

In the outgrowth assay (24-well plates; no thymidine) all cultures of unfractionated cells regressed. $T$ cell enriched populations from either rheumatoid or healthy siblings did not form cell lines, though B cell outgrowth persisted for up to 20 days in cultures of rheumatoid $\mathrm{T}$ cells in contrast with 9-12 days in $\mathrm{T} \frac{\mathrm{D}}{\mathrm{e}}$ cell cultures from healthy siblings. Isolated non- $\mathrm{T} \ddot{\Rightarrow}$ cells, however, from both patients but not their $\stackrel{\mathcal{D}}{\stackrel{9}{ }}$ HLA identical healthy siblings spontaneously transformed into permanent B cell lines.

Thorley-Lawson and coworkers described a scoring system of $1-4$, judged by phase contrast microscopy, where 1 represented dead cells; 2 living but not necessarily transformed cells and clumps; 3 transformed cell clumps; 4 a culture well overrun by transformed and proliferating cells. ${ }^{13}$ The results of the regression assay showed that in wells scoring 3 or 4 thymidine incorporation was high (Fig. 1).
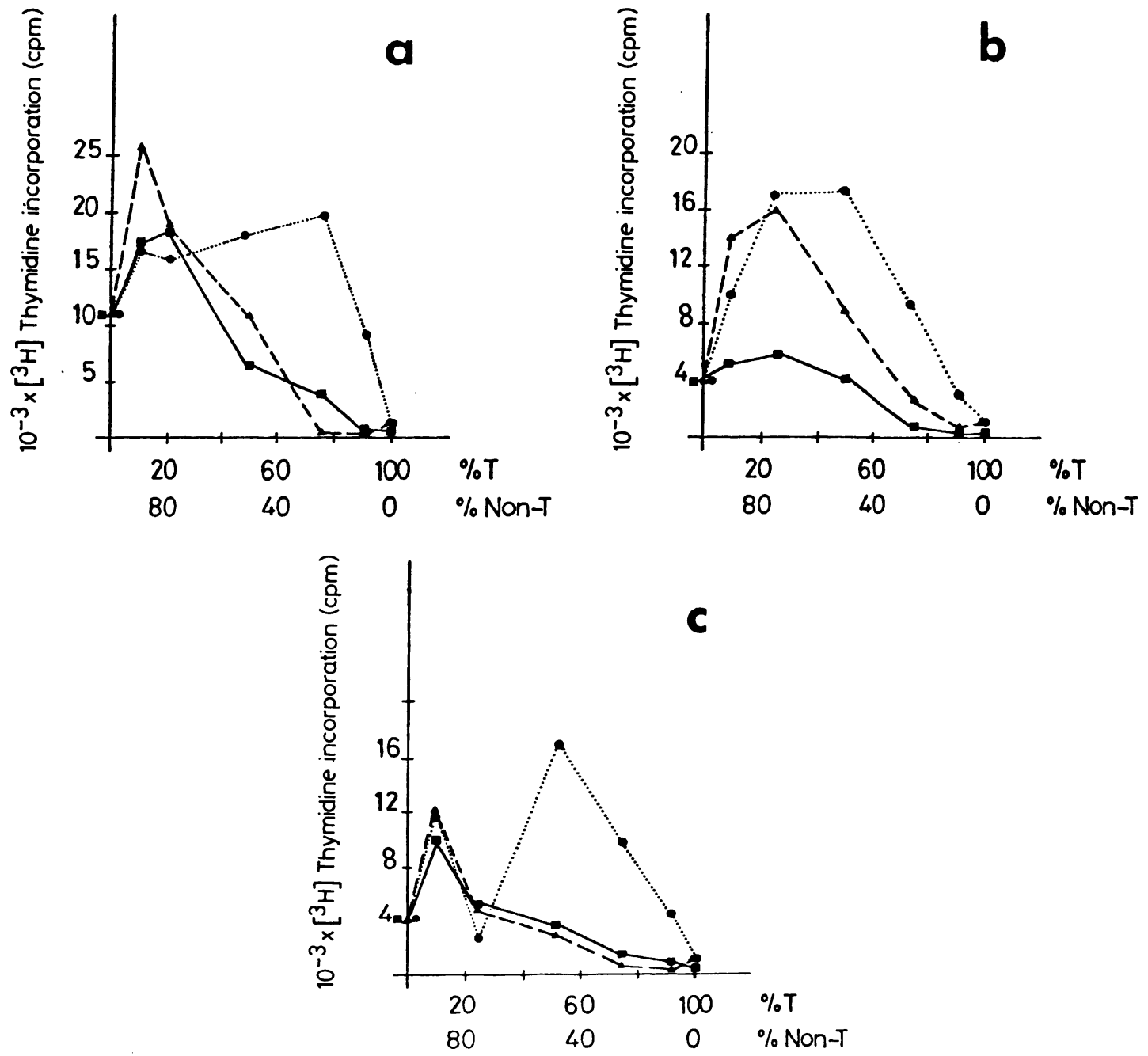

Fig. 1 Specific $T$ cell cytotoxicity to $E B V$ infected $B$ cells in family 1. Non-T cells from each sibling ((a) patient; $(b)$ sibling $A$; (c) sibling $B$ ) were transformed with $E B V$, and autologous or allogeneic $T$ cells were added at different ratios. $T$ cells are coded ........... 

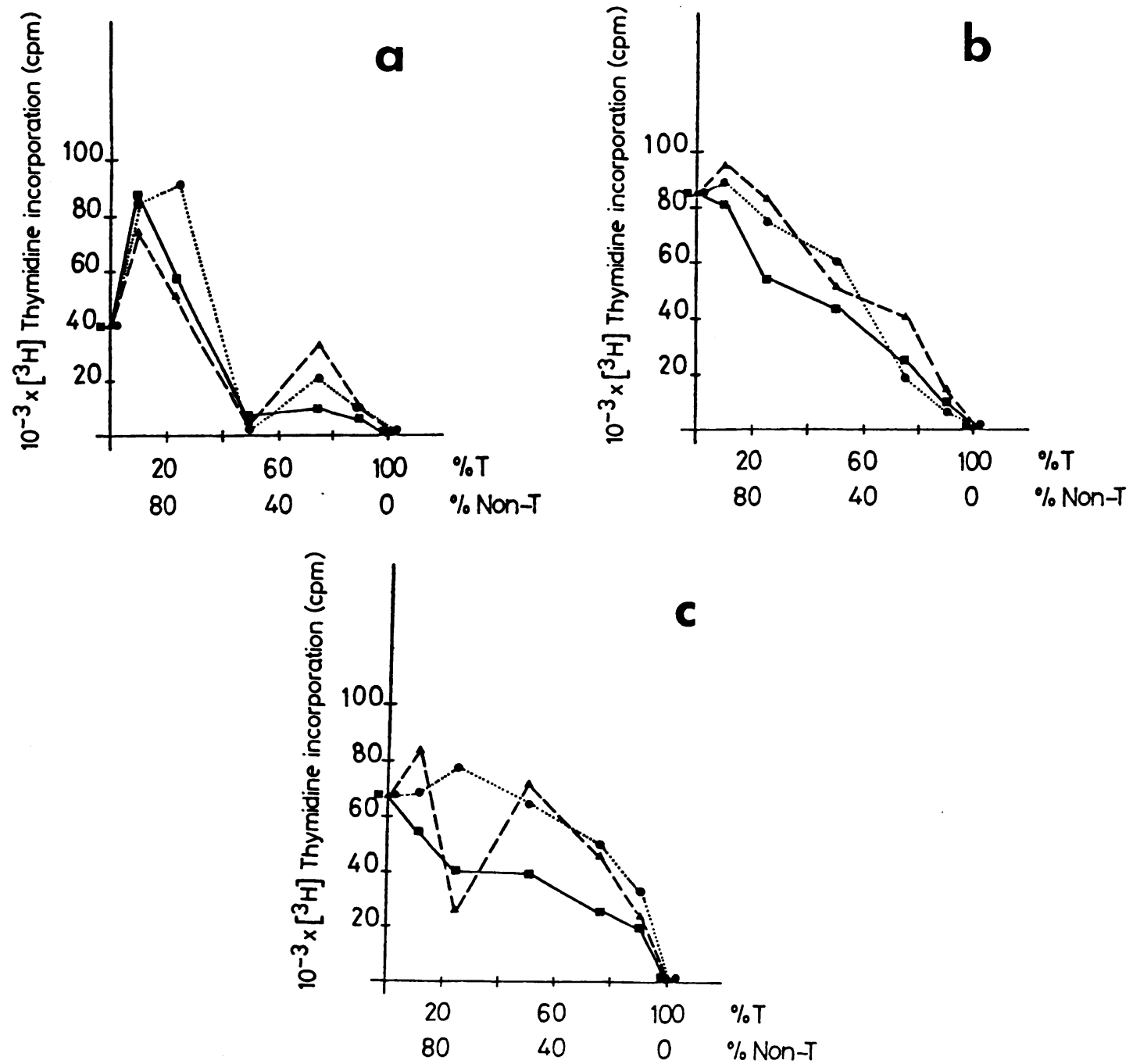

Fig. 2 Specific T cell cytotoxicity to EBV infected B cells in family 2. Non-T cells and T cells are coded as for Fig. 1 .

Regressing cultures scoring 1 (dead cells) or $3 / 1$ (small clusters of regressing transformed cells amongst dead cells) showed, respectively, background or slightly raised thymidine uptake. Table 2 gives an example referring to Fig. 1a.

Fig. 1 shows the regression assay results obtained with family 1 on day 14 of culture. B cells from the patient with RA were used in Fig. 1a: more than $75 \%$ autologous rheumatoid $T$ cells (T/B ratio of $3 / 1$ ) were required to prevent $B$ cell outgrowth in contrast with $50 \%$ (T/B ratio of $1 / 1$ ) HLA identical allogeneic normal $\mathrm{T}$ cells. This affirms that $\mathrm{T}$ cells from the rheumatoid patient show a defective cytotoxic response. This patient's $T$ cells were also less able to control the homologous $B$ cell outgrowth from the HLA identical siblings (Figs $1 b$ and c).

Fig. 2 shows the results obtained with family 2 on day 14 of culture. In this family the disease in the patient had been inactive for four years. There was no significant difference in thymidine uptake between the cells of the rheumatoid patient and the unaffected siblings at 14 days.

For both families there were no differences in thymidine uptake at seven days. At 21 days thymidine incorporation showed baseline values in family 1 but in family 2 some thymidine incorporation was 
seen at high rheumatoid $\mathrm{T}$ cell numbers $(75 \%)$, irrespective of whether the B cells were rheumatoid or normal in origin (data not shown).

Results obtained with family 3 (Table 1 ) require comment. This patient with RA also had clinically active disease at the time of venepuncture. The cells, however, became contaminated during the manipulations and subsequent culture and, at 14 days, only the plate containing rheumatoid B cells with autologous or healthy allogeneic HLA identical $T$ cells remained uncontaminated. The results were comparable with those in Fig. 1a, the deficiency in $\mathrm{T}$ cell control being apparent at B:T cell ratios of 25:75 (data not shown). At seven days thymidine uptake was similar in both autologous and homologous cultures.

\section{Discussion}

Families provide a means of obtaining HLA identical, disease discordant individuals, for whom any differences in the behaviour of their cells can be ascribed to disease rather than HLA type. This study contrasts three families each containing a patient with rheumatoid arthritis and healthy HLA identical siblings, the patients having either active (families 1 and 3 ) or inactive (family 2) rheumatoid disease.

It has been shown that regression is attributable to both EBV specific $T$ cell cytotoxicity and nonspecific autologous mixed lymphocyte reactions and that much of the thymidine uptake by in vitro EBV infected cells at seven days is due to the concomitant $\mathrm{T}$ cell expansion. ${ }^{16}$ In a previous study we concluded that enhanced thymidine incorporation at seven days by unfractionated cells from rheumatoid patients was indicative of $B$ cell hyperresponsiveness. ${ }^{10} \mathrm{We}$ now have further evidence, however, showing that other cell populations are responsible for the increased thymidine uptake and also that viral dose is an important factor in measurement of this hyperresponsiveness. ${ }^{17}$ In this study there was no significant difference in thymidine uptake at seven days between any of the cultures (results not shown). As regression normally occurs $10-14$ days after in vitro stimulation, any actively dividing cells present on day 14 in cultures not having completely regressed should be virus infected B cells, and it was at this time that differences in thymidine uptake were noted. Table 2 shows that the amount of thymidine incorporation appeared to represent the degree of regression, though no absolute correlations were made.

The patient in family 1 with active disease at the time of assay presents a picture (Fig. 1a) typical of results obtained by others using non-HLA matched individuals, ${ }^{5}$ and the patient in family 3 also showed? this pattern of reactivity. In family 2 , where the patient had 'burnt out' RA, the picture (Fig. 2a) is quite different, being indicative of normal $T$ celle cytotoxicity. Isolated B cells from both rheumatoid patients, however, formed permanent cell lines in? the absence of EBV. This was not true of their histocompatible siblings, confirming our previousen conclusion that rheumatoid B cells are abnormal in $\overrightarrow{0}$ this respect. ${ }^{10}$

The outgrowth measured at 21 days in family $2 \vec{\omega}$ requires comment. Increased thymidine levels were noted $(20000-40000 \mathrm{cpm})$. This may reflect a lackō of control by rheumatoid $T$ cells but is more probably due to rheumatoid $\mathrm{B}$ cell contamination of the rheumatoid $T$ cell population as the EBV infected rheumatoid $\mathrm{T}$ cell population also showed some outgrowth of $B$ cells, which regressed at 208 days. It must be remembered that the cell popula- tions are merely enriched for the various cell types and do not represent pure $B$ and $T$ cells.

One interesting aspect of these results is the age $\overrightarrow{0}$ difference of these families. Within each family age matching is reasonably close, but the age differences between families 1 and 2 are considerable, the patient in family 2 being almost 30 years older than the patient in family 1 . Most studies measuring agen related differences of immunity imply that $\mathrm{T}$ cello cytotoxicity is impaired in older individuals. ${ }^{18}$ Here $\stackrel{\varrho}{\rightleftarrows}$ the $\mathrm{T}$ cells of the older patient (family 2 ) behavedo efficiently, but the $T$ cells of the younger patient ${ }^{3}$ (family 1) were defective. This is consistent with out argument that the poor $\mathrm{T}$ cell regulation of the patient in family 1 is disease related. Others have $\frac{\text { a }}{2}$ suggested that the 'strength' of regression is relatedo to the degree of matching of major histocompatibil 3 . ity complex class 1 antigens, ${ }^{19}$ which is clearly not the explanation of the results in these experiments. It is possible that there are sex related differences, 0 but this study was not designed to assess that problem. Sibling B (F) in family 1 showed someo impairment in T cell control of EBV infected B cells (Fig. 1b) from sibling A (M). All three siblings ino family 2 were female.

Because of the small number of families recruited the information available from this study is limited 0 it suggests, however, that the inability of rheuma toid T cells to regulate $B$ cell outgrowth is related to disease activity, and studies by Gaston and co-s workers lend support to this conclusion. ${ }^{20}$ Also, it appears that the defect in T cell control in RA is reversible as the $T$ cells of the patient with burn out RA and those of the HLA identical siblings were equally effective in the regression assay Recent work, also using disease discordant histo compatible siblings, ${ }^{21}$ has shown abnormalities in 
the suppression of IgM production by EBV infected rheumatoid B cells, but no correlations were looked for with disease activity. In our study antibody production was not measured. Nevertheless, the spontaneous production of $\mathrm{B}$ cell lines by isolated non-T cells from the patients in families 1 and 2 supports our previous data from limiting dilution analysis, ${ }^{10}$ suggesting that there is an inherent B cell defect in RA which is disease related but, unlike the rheumatoid $\mathrm{T}$ cell defect, independent of disease activity.

We thank Danicl McCloskey and Juliette Awad of the department of immunology (Professor H Festenstcin) for tissuc typing the families. VRW was supported by the Arthritis and Rheumatism Council for Research.

\section{References}

1 Vaughan J H. Rheumatoid arthritis, rheumatoid factor and the Epstein-Barr virus. J Rheumatol 1979; 6: 381-8.

2 Depper J M, Zvaifler N J. Epstein-Barr virus. Its relationship to the pathogenesis of rheumatoid arthritis. Arthritis Rheum 1981; 24: 755-61.

3 Moss D J, Rickinson A B, Pope J H. Long-term T cellmediated immunity to Epstein-Barr virus in man. I. Complete regression of virus-induced transformation in cultures of seropositive donor leucocytes. Int $J$ Cancer 1978: 22: 662-8.

4 Bardwick P A, Blucstein H G. Zvaifler N J. Depper J M. Scegmiller J E. Altered regulation of Epstcin-Barr virus induced lymphoblast proliferation in rhcumatoid arthritis cells. Arthritis Rheum 1980; 23: 626-32.

5 Tosato G, Steinberg A D. Blacse R M. Defective EBV-specific suppressor $\mathrm{T}$ cell function in rheumatoid arthritis. $N$ Engl J Med 1981; 305: 1238-43.

6 Gaston J S H, Rickinson A B, Epstein M A. Epstein-Barr virus-specific cytotoxic $T$ cell responses in rheumatoid arthritis patients. Rheumatol Int 1982; 2: 155-9.

7 Hasler F, Blucstein H G, Zvaifler N J, Epstein L B. Analysis of the defects responsible for the impaired regulation of EpstcinBarr virus induced $B$ ccll proliferation by rhcumatoid arthritis lymphocytes. I. Diminished gamma interferon production in response to autologous stimulation. J Exp Med 1983: 157: 173-88.

8 Slaughter L, Carson D A. Jensen F C. Holbrook T L. Vaughan J H. In vitro effects of Epstcin-Barr virus on peripheral blood mononuclear cells from patients with rheumatoid arthritis and normal subjects. J Exp Med 1978; 148: 1429-34.
9 Tsoukas C D. Carson D A. Fong S. Slovin S F. Fox R I Vaughan J H. Lysis of autologous Epstein-Barr virus-infected B cells by cytotoxic $\mathrm{T}$ lymphocytes of rheumatoid arthritis patients. Clin Immunol Immunopathol 1982; 24: 8-14.

10 Stierle H E. Brown K A. Perry J D. Holborow E J. Increased responsiveness of rheumatoid $B$ lymphocytes to stimulation by Epstein-Barr virus. Rheumatol Int 1983; 3: 7-11.

11 Bøyum A. Separation of leukocytes from blood and bone marrow. Paper IV. Isolation of mononuclear cells and granulocytes from human blood. Scand J Clin Lab Invest 1968: 21 (suppl 97): 77-89.

12 Kaplan M E, Clark C. An improved rosetting assay for detection of human T lymphocytes. J Immunol Methods 1974: 5: $131-5$.

13 Thorley-Lawson D A. Chess L. Strominger J L. Suppression of in vitro Epstein-Barr virus infection. A new role for adult human T lymphocytes. J Exp Med 1977: 146: 495-508.

14 Ropes M W. Bennett G A. Cobb S. Diagnostic criteria for rheumatoid arthritis: 1958 revision. Ann Rheum Dis 1959; 18: 49-54.

15 Young A, Corbett M, Brook A. The clinical assessment of joint inflammatory activity in rheumatoid arthritis related to radiological progression. Rheumatology and Rehabilitation 1980; 19: 14-19.

16 Konttinen Y T. Bluestein H G. Zvaifler N J. Regulation of the growth of Epstein-Barr virus-infected B cells. A growth regression by $\mathrm{E}$ rosetting cells from VCA-positive donors is a combined effect of autologous mixed leukocyte reaction and activation of T8+ memory cells. J Immunol 1985; 134: 2287-93.

17 Winrow V R, Norton J. Perry J D. Holborow E J. Stierle H E. The effects of adherent cells on measurement of the hyperresponsiveness of rheumatoid B lymphocytes to Epstein-Barr virus. J Im!nunol Methods 1987: 97: 221-7.

18 Ohta Y. Fujiwara K. Nishi T. Oka H. Normal valucs of peripheral lymphocyte populations and $T$ cell subsets at a fixed time of day: a flow cytometric analysis with monoclonal antibodics in 210 healthy adults. Clin Exp Immunol 1986; 64: 146-9.

19 Moss D J, Wallace L E, Rickinson A B. Epstein M A. Cytotoxic $T$ cell recognition of Epstein-Barr virus-infected $B$ cells. I. Specificity and HLA restriction of effector cells reactivated in vitro. Eur J Immnunol 1981; 11: 686-93.

20 Gaston J S H, Rickinson A B. Yao Q Y. Epstcin M A. The abnormal cytotoxic $T$ cell response to Epstcin-Barr virus in rhcumatoid arthritis is correlated with disease activity and occurs in other arthropathies. Ann Rheum Dis 1986; 45: 932-6.

21 Fawcett M-C. Walker D J, Griffiths I D. Epstein-Barr virus induced B cell stimulation in R.A.: Demonstration of impaired $T$ suppressor activity using histocompatible disease discordant sibs. Br J Rheumatol 1986; 25 (suppl 2): 64. 